\title{
A Case of IgA-Binding-Type Macroamylasemia
}

\author{
Kazuomi Horis, MD, Yukihiko ADAChI, MD, Ichiro Kuwahara, MD \\ and Toshio Yamamoto, MD
}

\begin{abstract}
The serum amylase of an 83 year old man with no abdominal complaints, continuously high serum amylase activity and a remarkably low amylase clearance/creatinine clearance ratio was investigated and found to be IgA-binding type macroamylase. In electrophoresis of the serum amylase, a great majority of the phoretic band was in the globulin fraction. In Sephadex G-200 column gel chromatography, almost all amylase activity was found between the first and second protein peaks. When the patient's serum was acidified in vitro (pH 3.4), the amylase became normal in size and the change was reversible. The macroamylase was precipitated with anti-human IgA sheep serum. In enzymo-immunoelectrophoresis, amylase activity was found only in the IgA band. The urinary and salivary amylase in this patient was normal in size.
\end{abstract}

Key Words: Amylase, Ig A-binding macroamylase, Column gel chromatography, Enzymo-immunoelectrophoresis.

Low urinary amylase activity and low amylase clearance/creatinine clearance ratio (Gam/Ccr) with continuously high serum amylase activity are sufficient basis for a clinical diagnosis of macroamylasemia ${ }^{11}$. The binding substance which makes the amylase macromolecular is usually immunoglobulin, but there are cases in which some other unknown substances make this change.

Recently, the authors experienced one case of macroamylasemia and investigated the properties of his abnormal amylase.

\section{CASE PRESENTION}

The patient was an 83 year-old male. He had suffered from palpitation for 5 years. Although he had no other complaints, he had been found to have hyperamylasemia by his family doctor, and he consulted the Kinki University Hospital in May, 1977. He had been drinking two
Table 1. Labolatory Data

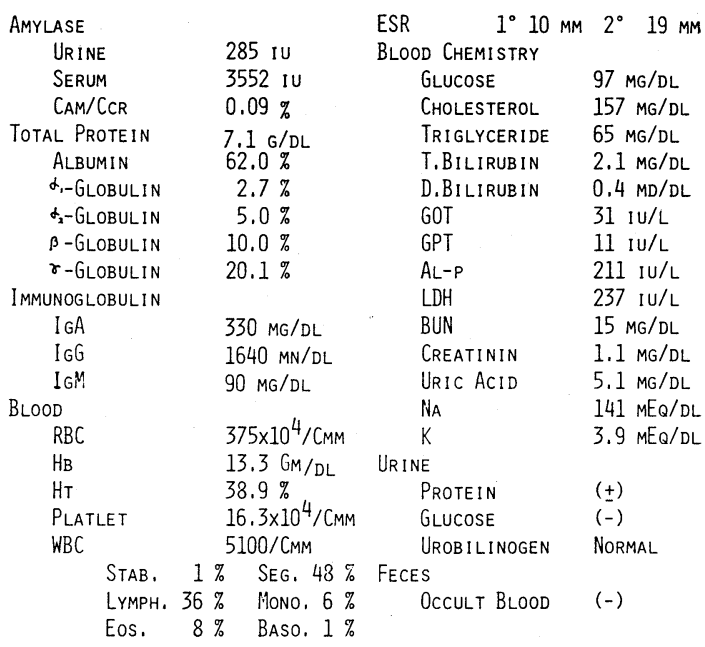

deciliters of sake (alcohol: 16\%) every day for 20 years. He was a normally developed and well-nourished man (height: $161 \mathrm{~cm}$, weight: $55 \mathrm{~kg}$ ). His pulse was 72

From the Second Department of Internal Medicine, Kinki University School of Medicine, Sayama-cho, Osaka-fu, 589 Japan.

Received for publication August 31, 1979.

Reprint request to: Dr Kazuomi Horii, The Second Department of Internal Medicine, Kinki University School of Medicine, Sayama-cho, Osaka fu, 589 Japan. 
per minute and irregular. His blood pressure was $110 / 72 \mathrm{mmHg}$. A systolic murmur was present in the fourth intercostal space at the left sternal line of the chest. The lungs showed no abnormality. The liver and spleen were not palpable and there was no swelling of the lymph nodes. The ECG showed atrial fibrillation, and only gastroptosis was seen in the upper GI series.

Laboratory data (Table 1):

Serum bilirubin was $2.1 \mathrm{mg} / \mathrm{d} l$, serum amylase was as high as 3,552 IU, and the $\mathrm{Cam} / \mathrm{Ccr}$ was as low as $0.09 \%$. The total serum protein fractions, and $\operatorname{Ig} \mathrm{A}, \mathrm{IgG}$ and IgM were all within the normal ranges.

\section{MATERIALS AND METHODS}

The specimens studied were serum, saliva and urine (Concentrated 25-fold with a PM 10 Amicon membrane) obtained from the patient. Sera obtained from a patient with gallstones (serum amylase: $620 \mathrm{IU}$, Cam/Gcr: $1.8 \%$ ), and from two healthy persons who had normal serum amylase activity and normal Cam/Ccr were used as controls for gel filtration and electrophoresis, respectively. Amylase was measured by the modified method of Caraway (Wako Amylase Kit, expressed as "units") or the blue starch polymer method" (expressed as "IU"). Amylase isozyme fractionation was performed by electrophoresis on a cellulose acetate membrane stained with blue starch.

Measurement of amylase molecule size: Sephadex G-200 gel filtrtion (eluent: physiological saline, column : $\varnothing 2.5 \times 100 \mathrm{~cm})$ was used. One milliliter of serum, $0.5 \mathrm{ml}$ of saliva and $2.1 \mathrm{~m} l$ of concentrated urine of the patient and $2 \mathrm{ml}$ of the control serum was applied to the gel. The protein content and amylase activity of the respective fractions were measured. To observe the normalization of the amylase size by the acidification of the macroamylase, $5.1 \mathrm{ml}$ of glycine $\mathrm{HCl}(0.05 \mathrm{M}, \mathrm{pH} 3.4)$ was added to $1.7 \mathrm{~m} l$ of patient's serum and
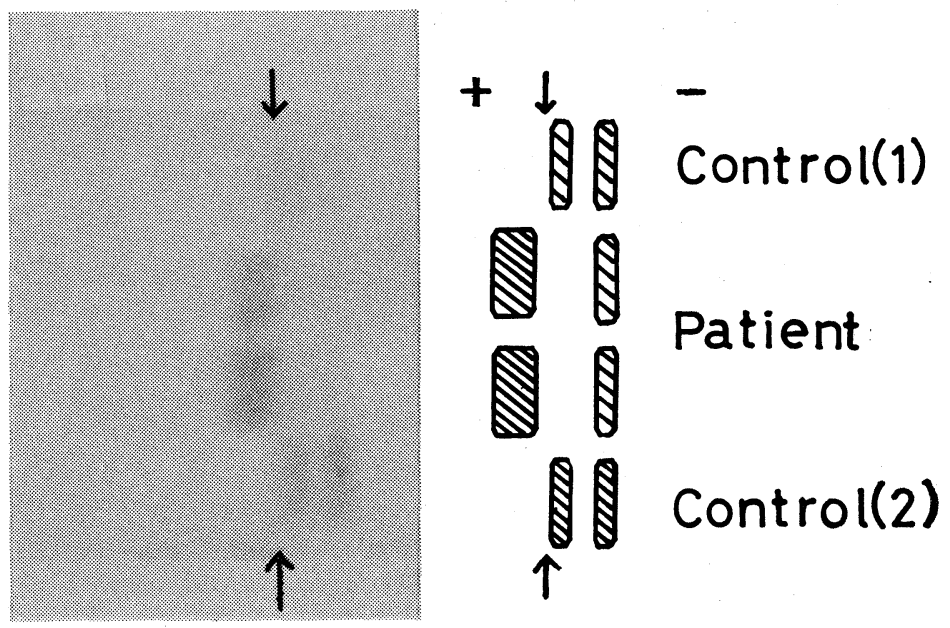

Fig. 1. Electrophoretic separation of serum amylase isoenzymes. Top and bottom levels show control sera from two normal volunteers and the middle two levels patient's serum. The arrow $(\uparrow)$ shows the origin. The anode is to the left. The amylase of the control sera moved from the origin toward the cathode and the amylase of the patient's serum moved mostly toward the anode. 

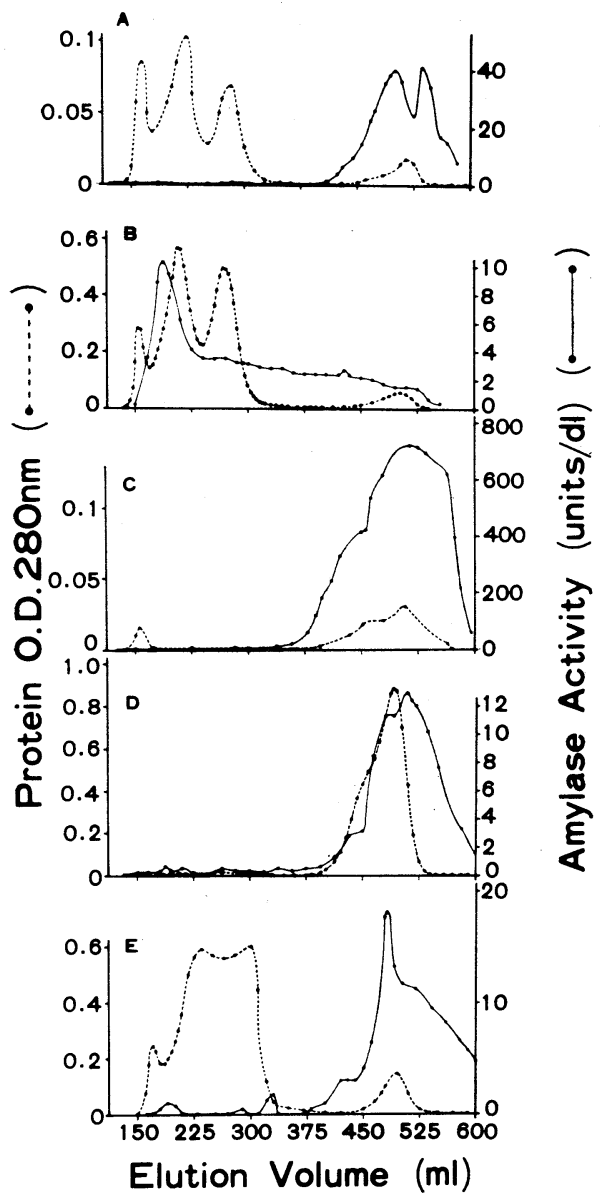

Fig. 2. Elution patterns of proteins and amylase from Sephadex G-200 $(\phi 2.5 \times 100 \mathrm{~cm})$

The solid lines show amylase activity and the broken lines the amount of protein.

(A) Control serum : amylase activity was found after the third protein peak.

(B) Patient's serum: amylase activity was high between the 1 st and 2 nd protein peaks.

(C) Patient's saliva and (D) concentrated patient's urine: The amylase activity for both $\mathrm{C}$ and $\mathrm{D}$ showed the same elution pattern as normal serum.

(E) Acidified patient's serum ( $\mathrm{pH} 3.4)$ : The molecular weight of the abnormal amylase was normalized.

after standing at room temperature for 30 minutes, gel filtration was performed on Sephadex G-200 using glycine-HCl buffer (0.5 M, pH 3.4) as the eluent. Into each

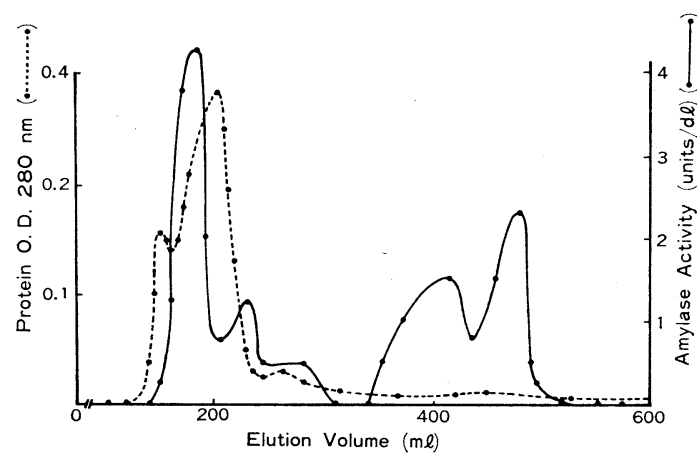

Fig. 3. The reversibility of the binding of amylase and protein fractions. After the normal sized amylase and protein fraction between the 1 st and 2 nd protein peaks of the acidified patient's serum were eluted from Sephadex G-200, they were neutralized and mixed, and the mixture was subjected to gel filtration with Sephadex G-75. The amylase activity again shifted to the macromolecular protein fractions.

fraction tube, $0.1 \mathrm{~m} l$ of $1 \mathrm{M}$ Tris-HCl buffer ( $\mathrm{pH}$ 7.2) was added beforehand. The amylase-lacking fraction between the first and second protein peaks and the normal sized amylase fraction were concentrated and mixed. The mixture was eluted by Sephadex G-75 $(\varnothing 2.5 \times 100 \mathrm{~cm})$.

Enzymo-immunoelectrophoresis: To investigate the binding of amylase with immunoglobulin, electrophoresis was performed using agarose film as a support, and the formation of immunoprecipitin lines with the specific antisera (anti-human $\operatorname{IgG}, \operatorname{Ig} \mathrm{A}$ and $\operatorname{IgM}$ immunoglobulins sheep sera, Hyland Co.) was observed. The precipitin lines were stained with blue starch at $37^{\circ} \mathrm{C}$ for 60 minutes.

Immune precipitation method: To investigate the binding of immunoglobulin with amylase, 2 to $40 \mu l$ of the patient's serum was added to $0.1 \mathrm{ml}$ of each of the anti-human-immuno-globulin sheep sera.

After standing at room temperature for 24 hours, the mixture was centrifuged at $3,000 \mathrm{rpm}$ for 10 minutes and the amylase activity of the supernatant was measured. After the precipitate was washed three times with physiological 


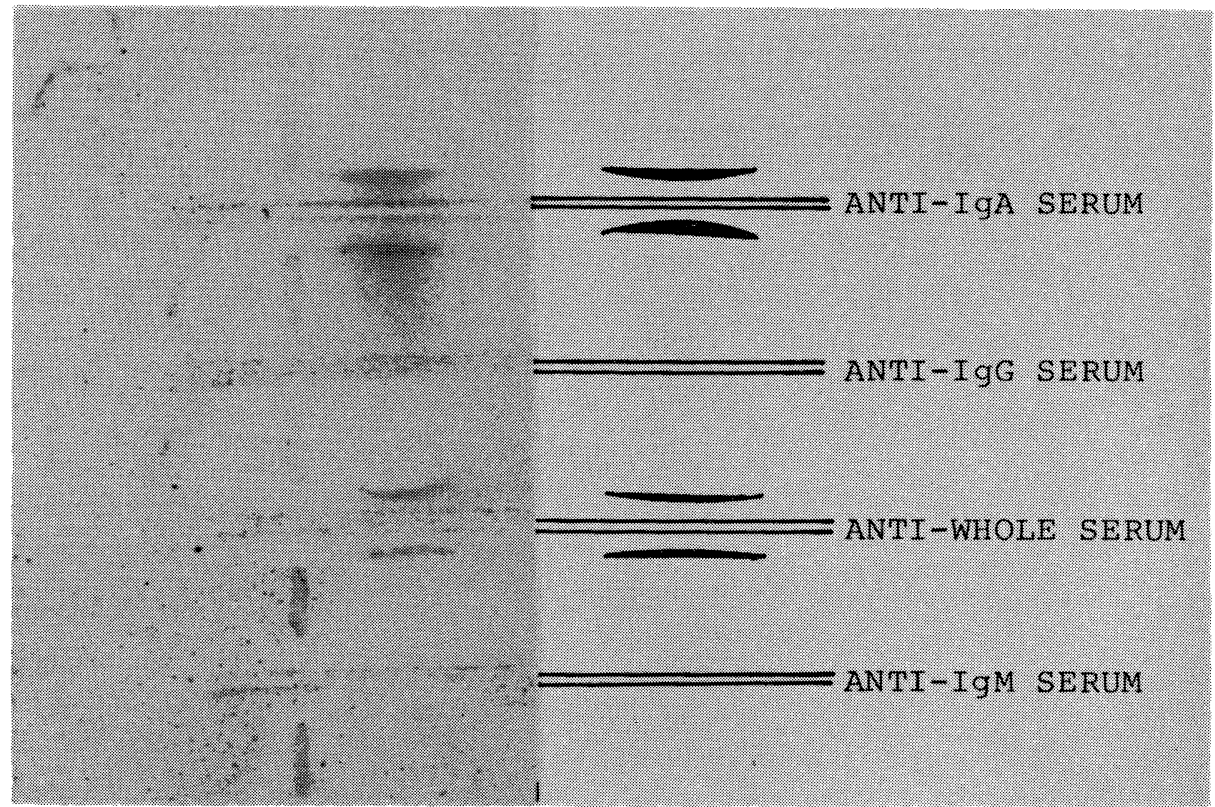

Fig. 4. Enzymo-immunoelectrophoresis of the patient's serum. There was obvious amylase activity in the specific precipitin line between anti-human IgA and patient's serum. Weak amylase activity was found only in the $\operatorname{Ig} \mathrm{A}$ specific precipitin line between antiwhole-humanserum sheep serum and patient's serum. The stained precipitin lines of this photograph are contrasted by penciling.

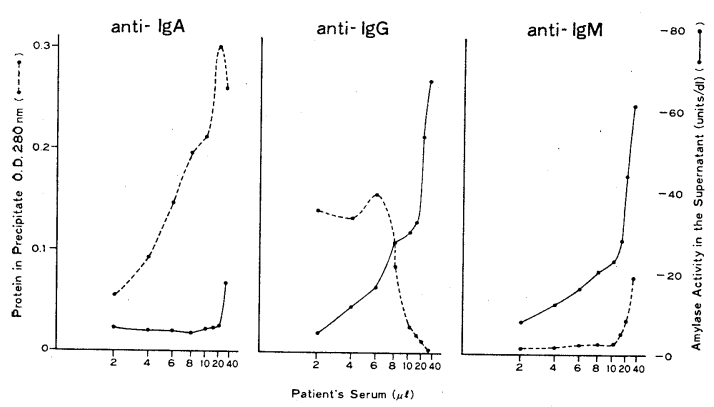

Fig. 5. Immuno precipitation of patient's serum. The solid lines show supernatant amylase activity and the broken ilnes the amouat of protein in the precipitate.

saline, it was dissolved in $2.4 \mathrm{ml}$ of $0.05 \mathrm{M}$ glycine HCl buffer ( $\mathrm{pH} 3.4)$ and the amount of protein was measured by $280 \mathrm{~nm}$ absorbancy.

\section{RESULTS}

For about six months, the patient's serum showed consistently high amylase activity, ranging from 3,148 to 4,420 IU. The Cam/Ccr showed a clearly low value of $0.09 \%$.

In electrophoresis of the patient's serum, P-type ${ }^{4)}$ was $12.4 \%$ (391 IU) and there was no S-type ${ }^{4)}$. Abnormal amylase (87.6\%, $2,757 \mathrm{IU})$ was found in the globulin fraction slightly toward the anode from the origin (Fig. 1).

In gel filtration using Sephadex G-200, human serum protein produces three peaks. The amylase of a gallstone patient's serum was eluted after the third protein peak (Fig. 2A). However, in the patient's serum, most of the amylase activity was found between the first and second protein peaks, and amylase activity in the other fractions was low (Fig. 2B). When the patient's serum was acidified and underwent gel filtration, the elution pattern was the same as that of the control serum (Fig. 2E). When the mixture was again neutralized and the protein was subjected to the same gel filtration, the amylase activity again 
shifted to the macromolecular protein fractions (Fig. 3). From these results, it was thought that the amylase was freed from the macromolecular substance when the serum was acidified and this change was incompletely reversed. The amylase in the patient's saliva and concentrated urine was of normal size (Fig. 2C and D).

In enzymo-immunoelectrophoresis, no amylase activity of the specific precipitin lines between the patient's serum and the anti-human immunoglobulins was found for IgG and IgM. There was amylase staining only in the specific precipitin line with anti-IgA. In the case of the patient's serum and anti-human-whole-serum, amylase activity was found only in the $\operatorname{IgA}$ specific precipitin line (Fig. 4).

The results of immune precipitation method, and the precipitation between the patient's serum and anti-human immunoglobulin (anti-IgA, anti-IgM and anti-IgG) are shown in Fig. 5. When the amount of antiserum was constant and the amount of patient's serum added was increased, the amount of protein precipitated increased but the supernatant amylase activity decreased slightly in the case of anti-human $\operatorname{Ig} \mathrm{A}$. In the case of anti-human IgG, the amount of precipitated protein and supernatant amylase activity increased up to $6 \mu l$ of patient's serum added, but at $8 \mu l$ and over, the amount of protein precipitated decreased and the supernatant amylase activity increased. In the case of antihuman IgM, the amount of protein precipitated and the supernatant amylase activity both increased in proportion to the amount of patient's serum between $10 \mu l$ and $40 \mu l$ added, but with under $10 \mu l$, the increase in the amount of protein precipitated was less than that of the supernatant amylase activity.

\section{DISCUSSION}

Chronic hyperamylasemia without renal disease was first reported by Sachar et al..$^{5}$ in 1956. Wilding et al. $^{6)}$ reported that the amylase was eluted between the $19 \mathrm{~S}$ and
$7 \mathrm{~S}$ protein fractions on Sephadex-G 100 and assumed that the binding protein for amylase was gamma-macroglobulin because the phoresis of the macromolecule was in the fast gamma-slow beta globulin position in electrophoresis. Berk et al. ${ }^{7,8)}$ designated this condition as macroamylasemia and postulated three possibilities: (1) polymerization of normal amylase, (2) binding of normal amylase and immunoglobulin or another protein, and (3) binding of normal amylase with a large non-protein molecule.

The case reported here was suspected clinically as a case of macroamylasemia because of continuous hyperamylasemia and a remarkably low Cam/Ccr.

Levitt $e t$ al. ${ }^{1)}$ reported that the Cam/Ccr is useful as a screening test for macroamylasemia because the values of the $\mathrm{Cam} / \mathrm{Ccr}$ are always low in macroamylasemia. The low Cam/Ccr indicates that the molecular weight of macroamylase is greater than 160,000. Molecules of this size are not filtered in appreciable quantities in the glomerulus. However, Berk et al..$^{9)}$ reported three cases which had low Cam/Ccr but no macroamylasemia. They concluded that the renal excretion capacity is greater for P-type amylase than for S-type amylase since there was an increase in $\mathrm{S}$ type amylase in three cases, or that there was a decrease in the in vivo inactivation of S-type amylase. Therefore, the low Cam/ Ccr dose not always mean the presence of macroamylase. However, by Cam/Ccr, which is simple to measure, should still be useful.

In 1968, Levitt ${ }^{10)}$ reforted a case of macroamylasemia with the 11 S-type amylase bound to IgA. This macroamylase was considered to result from the antigenantibody reaction. However, the authors believe that it is better not to consider this as a real antigen-antibody reaction since bound immunoglobulin does not act as a blocking antibody. There have been reforts of IgG-birding type macroamylasemia ${ }^{11}$, and 7 S-type macroamylasemia without binding to an immunoglobulin ${ }^{12)}$. 
Clinical symptoms ${ }^{13)}$ of macroamylasemia vary from patient to patient. Therefore, the actual cause of this disorder is not clear at present.

Fridhandler et al. ${ }^{14)}$ reported a binding substance in macroamylasemia, and found that the S-type amylase showed stronger affinity. The affinity was not investigated in the case reported here, but since no Stype amylase could be found in electrophoresis and there was only amylase activity bands in the P-type amylase fraction and the globulin fraction, it seems possible that S-type amylase becomes mainly macromolecular.

In column chromatography, it was found that the size of the macroamylase in this patient was mainly between $7 \mathrm{~S}$ and $19 \mathrm{~S}$.

The results of immune precipitation and enzymo-immunoelectrophoresis showed that macroamylase of the patient was bound to $\operatorname{IgA}$. In the case of anti-human IgG, the amount of precipitated protein decreased but supernatant amylase activity increased at $8 \mu l$ and over of patient's serum added: One of the reasons for this was thought to be the addition of a relatively smaller amount of anti-human IgG. However, the peak precipitate occurred with $6 \mu l$ of patient's serum, and no decrease of amylase activity was shown from 2 to $6 \mu l$ of patient's serum (Fig. 5).

Hyperamylasemia of macroamylase is not derived from the escaping of the enzyme from tissues as is typical in acute pancreatitis but is a disturbance in the amylase clearance from the blood. However, since macroamylase has enzyme activity in vivo, and the binding substances are not constant from case to case, macroamylasemia is a highly interesting disease.

The authors with to thank Mr. Kenichi Unno of Nippon Shoji K. K. for his help in the enzymoimmnnoelectrophoresis. An outline of the work in this paper was presented at the $21 \mathrm{st}$ Kinki
Regional Meeting of the Japanese Society of Gastroenterology (1978, Osaka).

\section{REFERENCES}

1) Levitt $\mathrm{MD}$, et al: The renal clearance of amylase in renal insufficiency, acute pancreatitis, and macroamylasemia. Ann Inter Med $71: 919,1969$.

2) Caraway WT: A stable starch for the determination of amylase in serum and other body fluids. Amer J Clin Path 32 : 97, 1959.

3) Ceska M, et al: A new and rapid method for the clinical determination of $\alpha$-amylase activities in human serum and urine. optinal conditions. Clin Chim Acta 26: 437, 1969.

4) Skude G: Electrophoretic separation, and variation of amylase isoemzymes. Scand J Glin Lab Invest $35: 41,1975$.

5) Sachar LA, et al: Misinterpritation of elevated blood diastase due to impaired renal clearance. AMA Arch Surg 6: 305, 1956.

6) Wilding $\mathrm{P}$, et al: Globulin-bound amylase. A cause of persistently elevated levels in serum. Ann Inter Med 60: 1053, 1964.

7) Berk JE, et al: A macroamylasemia: a newly recognized cause for elevated serum amylase activity. New Eng J Med $277: 941$, 1967.

8) Berk JE, et al: Macroamylasemia : serum and urine amylase characteristics. Amer J Gastroenterol $53: 223,1970$.

9) Berk JE, et al: Stimulation of macroamylasemia by salivary type ('S type') hyperamylasemia. Gut 14: 726, 1973.

10) Levitt MD, et al: Hyperamylasemia from the binding of serum amylase by an $11 \mathrm{IgA}$ globulin. New Eng J Med 278: 474, 1978.

11) Hansen HR, et al: Macroamylasemia due to binding by protein. Amer J Med 52 : $712,1972$.

12) Levitt MD, et al: Two forms of macroamylasemia. Lancet $4: 957,1968$.

13) Berk"JE, et al: Macroamylasemia : clinical and laboratory features. Amer J Gastroent $53: 211,1970$.

14) Fridhandler L, et al: Affinity characteristics of amylase-binding substance(s) prepared from macroamylase complexes. Glin Chem $20: 22,1974$. 